\title{
PENGARUH MATERI DAN METODE PELATIHAN TERHADAP KEMAMPUAN KERJA KARYAWAN PD BPR BANTUL, YOGYAKARTA
}

\author{
Yati Suhartini \\ Fakultas Bisnis, Universitas PGRI Yogyakarta \\ J1.PGRI I Sososewu No.117, Yogyakarta \\ Email: yati.suhartini@yahoo.com
}

\begin{abstract}
The research was carried out to find the influence of training material and methods of training toward workability. The study was conducted respectively from an employee of PD BPR Bantul Yogyakarta. The population of the research is 61 employees who have attended training. Data were derived from a survey, collected by applying questionnaires, analyzed by using multiple linear regression, and assisted by the application of the SPSS program. Based on the result of data analysis, it was shown that the three independent variables, namely training material (X1), on the job training (X2), and off the job training (X3) influence partially or simultaneously on workability $(Y)$, thus partially or simultaneously supporting the five hypotheses. Those were indicated by the value of the regression coefficient and the significant level of each factor, which are 0.407 and 0.008; 0.312 and 0.036; 0.443 and 0,000, respectively. Likewise, the value of $F$ amounting to 28,483 with the significance level of 0,000, whereas adjusted R2 counting to 0.579. Furthermore, off the job training indicates as the most dominant variable that influences on workability.
\end{abstract} work ability.

Keywords: training material, on the job training, off the job training, and

\section{Latar Belakang}

Perkembangan dunia perbankan saat ini sangat pesat dengan disertai adanya tantangan-tantangan yang semakin luas dan kompleks. Hal tersebut menjadikan perbankan harus cepat dan tanggap dalam menjalankan fungsi dan tanggung jawabnya melayani masyarakat. Untuk mewujudkan harapan tersebut, maka perlu didukung dengan karyawan yang mempunyai kemampuan kerja yang memadahai dalam menghadapi tantangan tersebut. Menurut Miftah Thoha (2012 ) mengemukakan bahwa kemampuan menunjukkan unsur kematangan yang berkaitan dengan pengetahuan dan ketrampilan yang dapat diperoleh melalui pendidikan dan pelatihan. Oleh karena itu, pelatihan harus benar-benar dapat mendorong peningkatan kemampuan kerja karyawan

Berkaitan dengan pelatihan, ada dua hal yang harus menjadi perhatian utama dalam pelaksanaan program pelatihan, yaitu materi pelatihan dan metode pelatihan (Mangkunegara, 2013). Materi pelatihan harus disesuaikan dengan kebutuhan, mampu menjawab permasalahan yang dihadapi, bermanfaat dalam kehidupan seharihari. Kebutuhan yang dimaksud bisa kebutuhan karyawan, namun bisa juga kebutuhan perusahaan. Selain itu, yang harus diperhatikan oleh perusahaan adalah membuat pelatihan dengan 
materi yang bermutu, praktis dan aplikatif. Materi pelatihan yang praktis, yaitu yang dapat dimengerti dan dipahami oleh para karyawan yang akan mengikuti training tersebut. Materi pelatihan yang aplikatif, yaitu dapat digunakan oleh karyawan dalam melakukan tugasnya sehari-hari di kantor.

Selain materi pelatihan, unsur lain yang harus diperhatikan dalam pelatihan yaitu metode pelatihan. Metode pelatihan sangat tergantung pada materi pelatihan yang akan diberikan. Tidak semua jenis metode pelatihan dapat diterapkan sesuai dengan materi pelatihan, karena hal itu tergantung situasi perusahaan dan kondisi peserta pelatihan (karywan). Perusahaan harus cermat memilih metode mana yang akan digunakan supaya tidak rugi waktu, tenaga dan biaya. Disisi lain proses pembelajaran harus digunakan metode yang tepat, agar supaya peserta pelatihan mampu menguasai ilmu pengetahuan dengan baik, keterampilannya meningkat, dan mampu berperilaku tertentu seperti yang diharapkan. (Mangkunegara, 2013).

Metode pelatihan dibagi menjadi dua, yaitu on the job training dan off the job training. Metode On the job training lebih banyak digunakan dibandingkan dengan off the job training, karena program on the job training lebih berfokus pada peningkatan produktivitas secara cepat. Sedangkan metode off the job training lebih cenderung berfokus pada perkembangan dan pendidikan jangka panjang. Untuk lebih memaksimalkan hasil dari kegiatan pelatihan, seringkali sebuah perusahaan menggabungkan beberpa metode pelatihan untuk memenuhi kemampuan karyawan yang dibutuhkan dalam perusahaan tersebut (Swasto, 2011)

Observasi awal pada PD BPR

Bantul, diketahui bahwa belum sepenuhnya karyawan didukung dengan kemampuan kerja tinggi dan memiliki legalitas pelatihan sesuai bidang kerjanya sehingga hasil kerja yang dicapai kurang optimal. Selain itu, penelaahan dan pengembangan penggunaan teknologi baru pada perusahaan perlu diimbangi peningkatan kemampuan personil pelaksananya. Perubahan sistem kerja maupun sistem yang lainnya pada perbankan akan berdampak pada proses interaksi sistem lama yang juga perlu diimbangi dengan adaptasi kerja dan pelaksanaannya. Program pelatihan yang awalnya dilakukan untuk meningkatkan kemampuan kerja tersebut tidak semuanya berjalan efektif. Materi pelatihan dan metode pelatihan yang diberikan belum semua sesuai dengan yang diharapkan dan dibutuhkan oleh karyawan.

Sehubungan dengan hal tersebut, maka salah satu aspek yang menarik untuk dikaji secara empirik,apakah pemilihan materi pelatihan dan penerapan metode pelatihan memiliki pengaruh yang signifikan terhadap kemampuan kerja karyawan PD BPR Bantul Yogyakarta.

\section{Rumusan Masalah}

Apakah variabel materi pelatihan, on the job training, dan off the job training secara parsial maupun simultan berpengaruh signifikan terhadap kemampuan kerja karyawan PD BPR Bantul Yogyakarta?

\section{Tujuan Penelitian}

Untuk mengetahui pengaruh variabel materi pelatihan, on the job training, off the job training secara parsial maupun simultan terhadap kemampuan kerja karyawan PD BPR Bantul Yogyakarta. 


\section{Manfaat Penelitian}

Bagi PD BPR Bantul, hasil penelitian ini akan memberikan informasi empiris tentang pengaruh variabel materi pelatihan, on the job training, off the job training secara parsial maupun simultan terhadap kemampuan kerja karyawan, sehingga informasi tersebut bisa menjadi masukan untuk perbaikan.

Bagi peneliti lain yang berminat dalam penelitian yang sama, hasil penelitian ini bisa digunakan sebagai referensi untuk melakukan penelitian lebih lanjut.

\section{Kajian Teori}

\section{- Materi Pelatihan}

Materi pelatihan dalam manajemen SDM merupakan bahan atau kurikulum yang sesuai dengan tujuan pengembangan SDM yang akan diwujudkan oleh perusahaan (Mangkunegara, 2013). Sedangkan menurut Kasmir (2016) , materi pelatihan merupakan materi atau bahan ajar yang akan diberikan kepada peserta pelatihan. Kedalaman materi yang diberikan tentu akan menambah pengertahuan peserta menjadi lebih baik, demikian pula sebaliknya. Materi pelatihan merupakan faktor penentu keberhasilan pelatihan. Oleh karena itu, materi pelatihan harus dibuat berdasarkan kebutuhan karyawan maupun perusahaan, dan harus disesuaikan dengan tujuan yang hendak dicapai.

Selanjutnya Sagala (2011) mengemukakan, ada beberapa poin penting yang harus diperhatikan dalam menyusun materi pelatihan, yaitu :

1. Materi hendaknya sesuai dengan atau menunjang tercapainya tujuan instruksional

2. Materi hendaknya wesuai dengan tingkat pendidikan dan perkembangan peserta didik
3. Materi hendaknya terorganisasi secara sistematis dan berkesinambungan

4. Materi hendaknya mencakup hal-hal yang bersifat faktual maupun konseptual

\section{- Metode Pelatihan}

Menurut Kamus Besar Bahasa Indonesia (KBBI), metode adalah cara teratur yang digunakan untuk melaksanakan suatu pekerjaan agar tercapai sesuai yang dikehendaki. Menurut Slameto (2010), metode yang kurang tepat dipilih akan berdampak tidak efektifnya proses pembelajaran dalam kegiatan pelatihan. Jadi, keberhasilan suatu program pelatihan sangat berkaitan dengan penggunaan metode pelatihan yang tepat. Sedangkan pelatihan yaitu setiap usaha untuk memperbaiki performansi pekerja pada suatu pekerjaan tertentu yang sedang menjadi tanggungjawabnya, atau suatu pekerjaan tertentu yang ada kaitannya dengan pekerjaannya (Gomes, 2003). Metode pelatihan terdiri dari bermacam-macam jenisnya dan tidak ada teknik atau metode yang dinilai paling baik (Handoko, 2014). Metode pelatihan yang dipakai sangat tergantung dari materi pelatihan, waktu dan tempat antara pelatih dan pesertanya, biaya, dan pertimbangan lain dari perusahaan.

Menurut Swasto (2011) teknikteknik pelatihan dibedakan menjadi dua, yaitu On the job training dan Off the job training. . Bangun (2012) menyatakan bahwa metode on the job training merupakan metode dimana para karyawan mempelajari pekerjaannya sambil mengerjakannya secara langsung dan metode off the job training merupakan pelatihan dilaksanakan dimana karyawan dalam keadaan tidak bekerjadengan tujuan agar terpusat pada kegiatan pelatihan saja. Maka, metode pelatihan yang 
digunakan haruslah tepat sesuai sasaran, diperlukan pertimbangan yang matang agar pelatihan yang dilakukan efektif sehingga berpengaruh positif terhadap kemampuan kerjakaryawan

\section{- On The Job Training}

Metode pelatihan on the job training dilakukan ditempat kerja yang sesungguhnya dan memberikan materi berupa tugas-tugas kepada karyawan untuk dikerjakan. Metode ini dilaksanakan dengan supervisi langsung seorang pelatih berpengalaman (biasanya karyawan yang lebih senior). Karyawan (peserta pelatihan) dihadapkan ke dalam situasi pekerjaan nyata dengan memberikan contoh-contoh pekerjaan yang baik dalam penanganan suatu pekerjaan secara langsung di tempat kerja dengan jelas dan nyata. Praktek yang bisa digunakan dalam on the job training adalah (Handoko, 2014) : 1) Rotasi Jabatan; 2) Latihan Instruksi Pekerjaan; 3) Magang ( Appreanticeships), 4) Coaching; 5) Penugasan Sementara Manfaat On The Job Training Menurut Simamora (2006) manfaat dari on the job training, antara lain yaitu:

1. Karyawan melakukan pekerjaan yang sesungguhnya bukan disimulasikan.

2. Karyawan menerima instruksi dari karyawan senior atau penyelia yang berpengalaman yang telah melaksanakan tugas dengan baik.

3. Pelatihan dilaksanakan didalam lingkungan kerja yang sesungguhnya, dibawah kondisi normal dan tidak membutuhkan fasilitas pelatihan khusus.

4. Pelatihannya informal, relatif tidak mahal, dan mudah dijadwalkan.

5. Pelatihan dapat membina hubungan kerja sama antara karyawan dan pelatih.
6. Program ini sangat relevan dengan pekerjaan, memakan biaya tunai yang relatif rendah, dan membantu memotivasi kinerja yangkuat

\section{- Off The Job Training}

Metode off the job training dilaksanakan diluar tempat kerja dan memberikan materi-materi tertentu kepada peserta pelatihan, yang meliputi tentang keahlian dan pengetahuan yang dibutuhkan untuk mengerjkan pekerjaan pada waktu yang terpisah dari waktu kerja reguler karyawan (Simamora, 2006). Pada off the job training tersebut seorang karyawan tidak lagi diposisikan pada tugas dan fungsi seperti biasanya. Macam-macam teknik yang digunakan dalam off the job training, yaitu (Handoko, 2014) :

1. Teknik Simulasi

Karyawan peserta latihan representasi tiruan (artificial) suatu aspek organisasi dan diminta untuk menanggapinya seperti dalam keadaan sebenarnya. Metode-metode simulasi yang paling umum digunakan adalah : a) Metode studi kasus; b) Role playing, c) Business games; d) Vestibule training; e) Laboratory training; f) Program pengembangan eksekutif

2. Teknik Presentasi Informasi

Teknik ini mengajarkan berbagai sikap, konsep atau keterampilan kepada peserta. Metode-metode yang biasa digunakan adalah: a) Kuliah; b) Presentasi Video; c) Metode Konferensi; d) Instruksi pekerjaan; e) Studi Sendiri Adapun manfaat off the job training menurut (Simamora, 2006) adalah:

1. Biaya pelatihan yang efisien, karena kelompok dan bukan individu yang dilatih 
2. Pelatih, biasanya instruktur yang kompeten daripada on the job trainer yang biasanya hanya mengorbankan sebagian kecil waktunya untuk melatih.

3. Kursus seminar yang off site memampukan perusahaan kecil dengan sumber daya yang terbatas untuk melatih karyawan tanpa mengeluarkan biaya yang mahal untuk staff pelatih dan fasilitas pelatihan.

4. Membuka wawasan karyawan terhadap perusahaan lain untuk mempelajari metode dan teknik baru di samping materi yang disajikan selama program.

5. Memampukan karyawan berkonsentrasi untuk mempelajari keahlian dan sikap baru tanpa harus sekaligus mengkhawatirkan pelaksanaan pekerjaan. Program ini juga mengurangi risiko bagi organisasi untuk mengkaryakan karyawan yang tidak memiliki pengetahuan yang memadai.

\section{- Kemampuan Kerja}

Kemampuan merupakan kecakapan seseorang yang meliputi kecerdasan dan keterampilan dalam memecahkan persoalan yang dihadapinya (Wursanto,2003). Robbins (2015) menjelaskan bahwa kemampuan merupakan kapasitas individu dalam menjalankan tugas pekerjaannya. Jadi, karyawan yang mempunyai kemampuan kerja berarti karyawan yang mampu untuk menyelesaikan tugas dan tanggungjawabnya sesuai dengan tuntutan yang diberikan oleh perusahaan.

\section{Hamalik}

mengemukakan bahwa kemampuan kerja individu bisa ditingkatkan melalui pelatihan, karena pelatihan menimbulkan perubahan-perubahan perilaku pada aspek-aspek kognitif, keterampilan dan sikap. Contoh-contoh kemampuan tersebut antara lain : 1) Kemampuan membentuk dan membina hubungan antar perorangan atau personal dalam organisasi. 2) Kemampuan menyesuaikan diri dengan keseluruhan lingkungan kerja. 3) Pengetahuan dan kecakapan untuk melakukan suatu pekerjaan tertentu. 4) Kebiasaan, pikiran dan tindakan serta sikap dalam pekerjaan.

Sedangkan Dulewicz dalam Sudarmanto (2009) membagi kemampuan dalam dimensi sebagai berikut : 1) Kemampuan intelektual, meliputi perspektif strategis, analisis penilaian, perencanaan dan pengorganisasian. 2) Kemampuan interpersonal, meliputi mengelola staf, sikap persuasive dan asertif, pengambilan keputusan, kepekaan interpersonal dan komunikasi lisan. 3) Kemampuan adaptabilitas, meliputi penyesuaian diri dengan lingkungan sekitar. 3) Kemampuan orientasi hasil, meliputi sikap energik dan inisiatif, motivasi berprestasi, dan kepekaan bisnis.

- Faktor-Faktor Yang Mempengaruhi Kemampuan Kerja

Faktor-faktor yang mempengaruhi kemampuan kerja seseorang yaitu : (Handoko, 2014)

1. Faktor pendidikan formal

2. Faktor pelatihan

3. Faktor pengalaman kerja.

\section{Penelitian Terdahulu}

Rizaldi Aga Pratama dan Mochamad Djudi Mukzam (2018) melakukan penelitian mengenai "Pengaruh Metode Pelatihan dan Materi Pelatihan Terhadap Kemampuan Kerja dan Kinerja Karyawan" (Studi Pada Karyawan Tetap PT Perkebunan Nusantara X Pabrik Gula Pesantren Baru Kediri), dan diperoleh hasil bahwa secara parsial variabel metode pelatihan dan 
$\begin{array}{lrr}\text { materi } & \text { pelatihan } & \text { berpengaruh } \\ \text { signifikan } & \text { terhadap } & \text { variabel }\end{array}$ kemampuan kerja.

Penelitian Dimas Anugrah, dkk, (2018) yang berjudul "Pengaruh On The Job Training dan Off The Job Training Terhadap Kemampuan Kerja dan Kinerja” (Studi pada karyawan PT. Insastama Kediri, Jawa Timur) diperoleh hasil bahwa Coaching, Rotasi Jabatan, Simulasi, dan Presentasi Informasi secara simultan memiliki pengaruh yang signifikan terhadap Kemampuan Kerja Karyawan maupun Kinerja Karyawan.

$$
\text { Eriza Violanda }
$$

Ekarendyka,dkk.(2016) melakukan penelitian mengenai "Pengaruh Pelatihan Terhadap Kemampuan Kerja dan Kinerja Karyawan" (Studi pada Karyawan AUTO 2000 Malang-Sutoyo bagian divisi service). Hasil penelitiannya yaitu terdapat pengaruh yang signifikan on the job training dan off the job training terhadap kemampuan kerja. Kemampuan kerja berstatus sebagai variabel moderator atau penguat dalam hubungan off the job training terhadap kinerja karyawan. Hal ini berarti off the job training akan mampu menaikkan kinerja lebih besar jika melalui peningkatan kemampuan

\section{Kerangka Penelitian}

Kerangka Penelitian digunakan untuk menggambarkan hubungan antar variabel yang ada dalam penelitian.Hubungan tersebut digambarkan dalam bentuk anak panah yang menandakan arah hubungan.

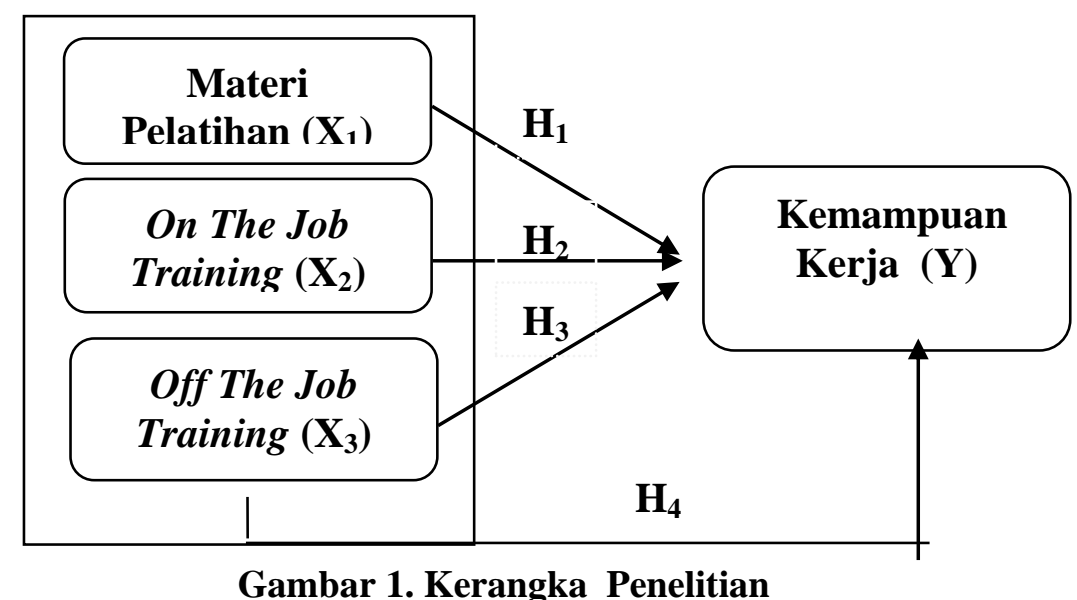

\section{Hipotesis Penelitian}

Berdasarkan rumusan masalah, tujuan penelitian, kajian teori dan kerangka penelitian, maka dirumuskan hipotesis penelitian sebagai berikut:

$\mathrm{H}_{1}$ : Diduga ada pengaruh yang signifikan antara variabel materi pelatihan terhadap kemampuan kerja karyawan PD BPR Bantul, Yogyakarta.

$\mathrm{H}_{2}$ : Diduga ada pengaruh yang signifikan antara variabel on the job training terhadap kemampuan kerja karyawan PD BPR Bantul, Yogyakarta

$\mathrm{H}_{3}$ : Diduga ada pengaruh yang signifikan antara variabel off the job training terhadap kemampuan kerja karyawan PD BPR Bantul, Yogyakarta

$\mathrm{H}_{4}$ : Diduga ada pengaruh yang signifikan antara materi pelatihan, on the job training ,dan off the job training secara simultan terhadap kemampuan kerja karyawan PD BPR Bantul, Yogyakarta. 
Metode Penelitian

- Jenis dan Pendekatan Penelitian

Penelitian ini menggunakan metode eksplanatory research, yaitu penelitian yang menjelaskan hubungan kausal antara variabel - variabel melalui pengujian hipotesis (Hermawan, 2009). Dalam penelitian kausal, vaiabel independen sebagai variabel sebab dan variabel dependen sebagai variabel akibat (Silalahi, 2010). Pendekatan yang digunakan dalam penelitian ini adalah pendekatan kuantitatif. Menurut Sugiyono (2014) jenis penelitian kuantitatif menggunakan data penelitian berupa angka-angka dan analisis menggunakan statistik serta menguji hipotesis.

- Subjek, Objek, dan Populasi Penelitian

Subjek penelitian ini adalah karyawan PD BPR Bantul Yogyakarta yang pernah mengikuti pelatihan kerja. Sedangkan objek penelitian ini adalah materi pelatihan, on the job training, off the job training, dan kemampuan kerja karyawan. Populasi penelitian ini sesuai subyek tersebut diatas adalah berjumlah 61 orang.

- Definisi Operasional Variabel dan Indikator Pengukuran

Variabel penelitian ini meliputi variabel bebas dan variabel terikat. Variabel bebas (X) terdiri dari materi pelatihan $\left(\mathrm{X}_{1}\right)$, on the job training $\left(\mathrm{X}_{2}\right)$, dan off the job training $\left(\mathrm{X}_{3}\right)$. Sedangkan variabel terikat yaitu kemampuan kerja (Y).

- Materi Pelatihan $\left(\mathrm{X}_{1}\right)$ Yang dimaksud materi pelatihan dalam penelitian ini adalah materi atau bahan ajar yang akan diberikan kepada peserta pelatihan dan telah disesuiakan dengan tujuan yang akan dicapai.

Indikator materi pelatihan menurut Mangkunegara (2013) meliputi:
1. Materi sesuai dengan tujuan.

Desain materi pelatihan harus mengacu pada tujuan instruksional dari pembelajaran. Kesesuaian antara materi pelatihan dan tujuan pelatihan sangat penting karena keberhasilan pelatihan dapat dilihat dari sejauhmana berhasilnya pencapaian tujuan pelatihan tersebut.

2. Materi sesuai dengan komponen peserta

Materi harus sesuai dengan tingkat kemampuan komponen peserta, yang telah dipilih melalui proses seleksi peserta

3. Penetapan sasaran

Penetapan sasaran berguna untuk mendorong peserta pelatihan dapat mengaplikasikan materi yang telah disampaikan dalam pelaksanaan pekerjaannya.

4. Kesesuaian isi materi dengan topik pelatihan yang telah disesuaikan dengan tujuan pelatihan.

- On The Job Training $\left(\mathrm{X}_{2}\right)$ Yang dimaksud $O n$ The Job Training adalah semua upaya melatih karyawan yang dilaksanakan di tempat kerja yang sesungguhnya dan dilakukan sambil bekerja

- Off The Job Training $\left(\mathrm{X}_{3}\right)$

Sedangkan yang dimaksud $O f f$ The Job Training yaitu pelaksanaan pelatihan yang berlangsung diluar situasi kerja normal, dan dilakukan tidak berkenaan dengan pekerjaan, tapi berfokus pada perkembangan dan pendidikan jangka panjang.

Indikator On The Job Training dan Off The Job Training

Sistem penilaian $O n$ The $J o b$ Training dan Off The Job Training menggunakan indikator berikut ini (Mangkunegara,2013) :

1. Menyesuaikan dengan tujuan materi pelatihan. 
Metode pelatihan harus sesuai dengan materi yang hendak yang akan disampaikan, agar peserta dapat menangkap maksud dan tujuan dari yang disampaikan oleh instruktur.

2. Memiliki sasaran yang jelas

3. Metode yang digunakan harus menarik bagi peserta

4. Adanya harmonisasi kegiatan pelatihan dengan keberlanjutan kegiatan di lapangan

5. Fasilitas pendukung metode pelatihan memadahi

6. Kesesuaian waktu pendukung pelaksanaan metode pelatihan yg dipilih

- Kemampuan Kerja (Y)

Yang dimaksud dengan

kemampuan kerja yaitu potensi yang dimiliki oleh karyawan untuk melaksanakan tugas atau pekerjaan.

Indikator kemampuan kerja menurut Blanchard dan Hersey (2005), meliputi

1. Kemampuan teknis, yang terdiri atas : penguasaan terhadap peralatan

kerja dan sistem komputer, penguasaan terhadap prosedur dan metode kerja,

memahami peraturan tugas atau pekerjaan.

2. Kemampuan konseptual, yang terdiri atas : memahami kebijakan perusahaan, memahami tujuan perusahaan, memahami target perusahaan.

3. Kemampuan sosial, yang terdiri atas : mampu bekerjasama dengan teman tanpa konflik, kemampuan untuk bekerja dalam tim, kemampuan untuk berempati

- Teknik Pengumpulan Data dan Pengukuran

Teknik pengumpulan data dalam penelitian ini menggunakan kuesioner yang terdiri atas pernyataan yang dibuat sesuai dengan indikator dari masing-masing variabel. Selain itu, pengumpulan data juga dilakukan melalui wawancara, observasi, dan dokumen perusahaan.

Pengukuran data menggunakan skala likert yang terdiri dari pilihan jawaban dan skor, sepertri berikut: Sangat Setuju=SS (skor 5), Setuju=S (skor 4), Netral=N (skor 3), Tidak Setuju=TS (skor 2), dan Sangat Tidak Setuju=STS (skor 1).

\section{- Uji Instrumen}

1. Uji Validitas

Uji validitas bertujuan untuk mengetahui alat ukur yang dipergunakan valid atau tidak untuk mengukur sesuatu yang seharusnya di ukur. Pengolahan data uji validitas dengan bantuan program SPSS versi 16 menggunakan teknik Pearson Correlation. Butir pertanyaan dikatakan valid jika $r$ hitung $>r$ tabel dengan ketentuan $r$ tabel minimal adalah 0,3 (Sugiyono.2014). Jika kriteria validitas memggunakan nilai $\mathrm{p}$ value, maka butir pertanyaan dikatakan valid jika nilai $\mathrm{p}$ value atau nilai signifikansi hitung kurang dari 0,05 .

\section{Uji Reliabilitas}

Kuesioner yang lolos pada uji validitas, selanjutnya dilakukan pengujian reliabilitas, yang bertujuan untuk menguji konsistensi hasil jika alat ukur digunakan untuk pengukuran berulang. Pengujian reliabilitas dilakukan dengan uji koefisien Cronbach Alpha. Kriteria instrumen reliabel adalah ketika nilai koefisien Cronbach Alpha lebih besar (>) 0,60 (Sugiyono.2014).

\section{- Teknik Analisis Data}

1. Analisis Regresi Linier Berganda

Data yang terkumpul selanjutnya dianalisis dengan menggunakan regresi linier berganda dan diproses dengan bantuan aplikasi SPPS versi 16. Alat analisis regresi 
berganda digunakan untuk mengetahui besarnya perubahan variabel terikat yang disebabkan oleh perubahan yang terjadi pada variabel bebas (Sugiyono, 2014).

Rumus regresi linier berganda sebagai berikut: $Y=a+b_{1} X_{1}+b_{2} X_{2}+b_{3} X_{3}$

Keterangan :

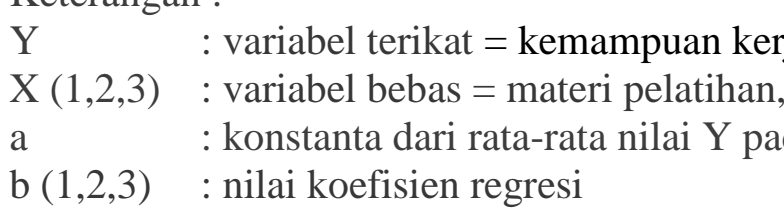

2. Uji Hipotesis

a. Uji t

Uji $\mathrm{t}$ digunakan untuk mengetahui pengaruh secara parsial variabel bebas $(\mathrm{X})$ terhadap variabel terikat (Y). Uji t dilakukan dengan menggunakan ketentuan angka probabilitas signifikansi $(\alpha=5 \%)$ : apabila nilai sig uji $\mathrm{t} \leq 0,05$, artinya variabel bebas secara parsial memiliki pengaruh signifikan terhadap varibel terikat (Sugiyono, 2014)

\section{b. Uji F}

Uji F digunakan untuk mengetahui pengaruh secara simultan atau serentak, variabel bebas terhadap variabel terikat. Dengan ketentuan jika nilai signifikasi uji $\mathrm{F}<0,05(\alpha=5 \%)$, maka variabel bebas secara simultan berpengaruh signifikansi terhadap variabel terikat (Sugiyono, 2014).

\section{c. Koefisien Determinasi ( $\mathrm{R}^{2}$ )}

Koefisien determinasi

digunakan untuk mengetahui prosentase sumbangan pengaruh variabel bebas $\left(\mathrm{X}_{1}, \mathrm{X}_{2}, \mathrm{X}_{\mathrm{n}}\right)$ secara serentak terhadap variabel terikat $(\mathrm{Y})$. Besarnya pengaruh variabel bebas (materi pelatihan, on the job training, dan off the training) terhadap variabel terikat ( kemampuan kerja) dapat diketahui dengan cara melihat besarnya koefisien determinasi (adjusted $R$ square). Koefisien ini juga menunjukkan seberapa besar prosentase variasi variabel bebas yang digunakan dalam model mampu menjelaskan variasi variabel terikat (Sugiyono, 2014)

\section{Hasil Penelitian}

\section{- Hasil Uji Validitas dan Reliabilitas}

Uji validitas dilakukan pada 34

butir kuesioner, dengan perincian sebagai berikut: kuesioner materi pelatihan berjumlah 8 butir, kuesioner pelatihan berjumiah o butir kuesioner on the $10 b$ training berjumlah \& butir, kuesioner ${ }_{\text {off sama dise job training }}$ berjumlah 8 butir, dan kuesioner kemampuan kerja berjumlah 10 butir. Dari pengolahan data diperoleh hasil bahwa koefisien korelasi berada pada kisaran 0,378 - 0,915. Ini berarti, 34 butir kuesioner dapat dikatakan valid karena nilai $r$ hitung yang dimiliki tiap butirnya lebih besar dari 0,3. Selain itu, hasil nilai $\mathrm{p}$ value atau nilai signifikansi hitung untuk semua butir pernyataan kurang dari 0,05. Dengan demikian, semua butir kuesioner dinyatakan valid sebagai alat pengumpul data.

Selanjutnya, hasil uji reliabilitas semua butir pertanyaan yang valid tersebut memperlihatkan bahwa nilai Cronbach's Alpha berada pada kisaran 0,689 - 0,907 atau lebih besar dari 0,6 sehingga butir-butir pertanyaan dalam seluruh variabel penelitian dinyatakan reliabel, serta dapat digunakan untuk penelitian selanjutnya.

\section{- Karakteristik Responden}

Dari kuesioner yang dibagikan kepada 70 karyawan PD BPR Bantul Yogyakarta, diperoleh informasi bahwa responden yang pernah mengikuti pelatihan berjumlah 61 orang. Oleh karena itu, penggunaan data penelitian hanya diperlakukan pada 61 responden. Berdasarkan jenis kelamin dapat diketahui bahwa karyawan dengan jenis kelamin laki-laki berjumlah 34 orang atau 55,7\% sedangkan karyawan dengan jenis kelamin perempuan adalah 27 orang atau $44,3 \%$. 
Berdasarkan karakteristik usia responden dapat diketahui bahwa responden yang berusia $<40$ tahun berjumlah 27 orang atau 44,3\%. Sedangkan responden yang berusia 41 50 tahun berjumlah 32 orang atau 52,5 $\%$. Responden yang berusia $>50$ tahun berjumlah 2 orang atau 3,2\%. Hal ini menunjukkan bahwa usia responden produktif muda dan produktif lanjutan relatif seimbang.

Berdasarkan pendidikan terakhir responden, diketahui bahwa pendidikan paling rendah Diploma berjumlah 4 orang atau $6,5 \%$ dan
Sarjana 57 orang atau 93,5\%. Hal ini menunjukkan bahwa pendidikan responden sebagaian besar sarjana.

Berdasarkan masa kerja responden, diketahui bahwa masa kerja kurang dari 10 tahun berjumlah 23 orang atau $37,7 \%$; masa kerja antara 11 sampai 15 tahun berjumlah 29 orang atau $47,5 \%$ dan masa kerja $>15$ tahun berjumlah 9 orang atau 14,8\%. Dari data tersebut dapat disimpulkan bahwa sebagian besar karyawan telah mempunyai masa kerja yang cukup lama yaitu lebih dari 10 tahun.

\section{- Hasil Regresi Linier Berganda}

Tabel 1. Hasil Regresi Linear Berganda

\begin{tabular}{|l|l|l|l|l|}
\hline \multicolumn{1}{|c|}{ Variabel Bebas } & $\begin{array}{l}\text { Koefisien } \\
\text { Regresi }(\mathrm{b})\end{array}$ & t-hitung & Sig & Kesimpulan \\
\hline Materi pelatihan $\left(\mathrm{X}_{1}\right)$ & 0,407 & 2,740 & 0,008 & Signifikan \\
\hline On the job training $\left(\mathrm{X}_{2}\right)$ & 0,312 & 2,153 & 0,036 & Signifikan \\
\hline Off the job training $\left(\mathrm{X}_{3}\right)$ & 0,443 & 3,956 & 0,000 & Signifikan \\
\hline Konstanta $=2.945$ & Adjusted $\mathrm{R}^{2}=0,579$ \\
\hline $\mathrm{F}=28.483$ (Sig $\mathrm{F}=0,000)$ \\
\hline Variabel Dependen : Kemampuan Kerja \\
\hline
\end{tabular}

Sumber : Hasil Pengolahan Data Primer 2019.

Berdasarkan tabel 1 diatas, maka dapat disusun persamaan regresinya, adalah : $\mathrm{Y}=2,945+0,407 \mathrm{X}_{1}+0,312 \mathrm{X}_{2}+0,443 \mathrm{X}_{3}$

Persamaan regresi tersebut memberikan informasi sebagai berikut:

1. Konstanta (a) sebesar 2,945, berarti bahwa jika koefisien variabel materi pelatihan, on the job training, dan off the job training sama dengan nol maka nilai kemampuan kerja karyawan sebesar 2,945 satuan.

2. Koefisien regresi X1 sebesar positif 0,407 berarti, bahwa jika koefisien variabel materi pelatihan naik satu satuan dan variabel lain konstan, maka nilai kemampuan kerja akan naik sebesar 0,407 satuan.

3. Koefisien regresi X2 sebesar positif 0,312 berarti, bahwa jika koefisien variabel on the job training naik satu satuan dan variabel lain konstan, maka nilai kemampuan kerja akan naik 0,312 satuan.

4. Koefisien regresi X3 sebesar positif 0, 443 berarti bahwa jika koefisien variabel off the job training naik satu satuan dan variabel lain konstan, maka nilai kemampuan kerja karyawan akan naik 0,456 satuan. 
- Hasil Uji Hipotesis

1. Uji t (Uji Parsial)

Tabel 2. Hasil Uji t

\begin{tabular}{|c|c|c|c|c|c|}
\hline \multirow[b]{2}{*}{ Model } & \multicolumn{2}{|c|}{$\begin{array}{l}\text { Unstandardized } \\
\text { Coefficients }\end{array}$} & \multirow{2}{*}{\begin{tabular}{|c|}
$\begin{array}{l}\text { Standardize } \\
\mathrm{d} \\
\text { Coefficients }\end{array}$ \\
Beta \\
\end{tabular}} & \multirow[b]{2}{*}{$\mathrm{t}$} & \multirow[b]{2}{*}{ Sig. } \\
\hline & $\mathrm{B}$ & Std. Error & & & \\
\hline 1 (Constant) & 2.945 & 5.144 & & .573 & .569 \\
\hline Materi pelatihan $\left(\mathrm{X}_{1}\right)$ & .407 & .148 & .310 & 2.740 & .008 \\
\hline On the job training $\left(\mathrm{X}_{2}\right)$ & .312 & .145 & .195 & 2.153 & .036 \\
\hline Off the job training $\left(\mathrm{X}_{3}\right)$ & .443 & .112 & .439 & 3.956 & .000 \\
\hline
\end{tabular}

Sumber : Hasil Pengolahan Data Primer 2019.

Pengujian secara parsial masing-masing variabel bebas sebagai berikut :

1. Pengujian Hipotesis Pertama $\left(\mathrm{H}_{1}\right)$

Pada tabel 2 menunjukan bahwa variabel materi pelatihan $\left(\mathrm{X}_{1}\right)$ memiliki koefisien regresi sebesar 0,407 yang bernilai positf, berarti variabel materi pelatihan mempunyai pengaruh positif terhadap kemampuan $\operatorname{kerja}\left(\mathrm{Y}_{1}\right)$, dan tingkat sifnifikan sebesar 0,008 yaitu kurang dari 0,05, berarti materi pelatihan $\left(\mathrm{X}_{1}\right)$ berpengaruh signifikan terhadap kemampuan $\operatorname{kerja}\left(\mathrm{Y}_{1}\right)$ karyawan PD BPR Bantul. Dengan demikian hipotesis pertama $\left(\mathrm{H}_{1}\right)$ diterima.

2. Pengujian Hipotesis Kedua $\left(\mathrm{H}_{2}\right)$

Pada tabel 2 menunjukan bahwa variabel On the job training $\left(\mathrm{X}_{2}\right)$ memiliki koefisien regresi sebesar 0,312 yang bernilai positf, berarti variabel On the job training mempunyai pengaruh positif terhadap kemampuan $\operatorname{kerja}\left(\mathrm{Y}_{1}\right)$, dan tingkat sifnifikan sebesar 0,036 yaitu kurang dari 0,05, berarti On the job training $\left(\mathrm{X}_{2}\right)$ berpengaruh signifikan terhadap kemampuan $\operatorname{kerja}\left(\mathrm{Y}_{1}\right)$ karyawan PD BPR Bantul. Dengan demikian hipotesis kedua $\left(\mathrm{H}_{2}\right)$ diterima.

3. Pengujian Hipotesis Ketiga $\left(\mathrm{H}_{3}\right)$

Pada tabel 2 menunjukan bahwa variabel Off the job training $\left(\mathrm{X}_{3}\right)$ memiliki koefisien regresi sebesar 0,443 yang bernilai positf, berarti variabel Off the job training mempunyai pengaruh positif terhadap kemampuan kerja $\left(\mathrm{Y}_{1}\right)$, dan tingkat sifnifikan sebesar 0,000 yaitu kurang dari 0,05, berarti Off the job training $\left(\mathrm{X}_{3}\right)$ berpengaruh signifikan terhadap kemampuan $\operatorname{kerja}\left(\mathrm{Y}_{1}\right)$ karyawan PD BPR Bantul. Dengan demikian hipotesis ketiga $\left(\mathrm{H}_{3}\right)$ diterima. 


\section{Uji F (Uji Simultan)}

Tabel 3. Hasil Uji F

\begin{tabular}{|l|r|r|r|c|c|}
\hline Model & Sum of Square & df & Mean Square & F & Sig. \\
\hline 1 Regression & 786.400 & 3 & 262.133 & 28.483 & $.000^{\mathrm{a}}$ \\
Residual & 524.583 & 57 & 9.203 & & \\
Total & 1310.984 & 60 & & & \\
\hline
\end{tabular}

Sumber : Hasil Pengolahan Data Primer 2019

4. Pengujian Hipotesis Keempat $\left(\mathrm{H}_{4}\right)$

Berdasarkan tabel 3 di atas menunjukan hasil uji anova memiliki nilai $\mathrm{F}$ sebesar 28,483 dengan nilai signifikan sebesar 0,000 yang lebih kecil dari 0,05. Hal ini menunjukan bahwa secara bersama-sama variabel Materi pelatihan, On the job training, dan Off the job training mempunyai pengaruh yang signifikan terhadap kemampuan kerja karyawan PD BPR Bantul. Dengan demikian hipotesis keempat $\left(\mathrm{H}_{4}\right)$ diterima.

- Koefisien determinasi $\left(\mathbf{R}^{2}\right)$

Tabel 4. Hasil Koefisien Determinasi

\begin{tabular}{|l|c|r|r|r|}
\hline Model & \multicolumn{1}{|c|}{$\mathrm{R}$} & $\mathrm{R}$ Square & Adjusted R Square & Std. Error of the Estimate \\
\hline 1 & $.775^{\mathrm{a}}$ & .600 & .579 & 3.034 \\
\hline
\end{tabular}

Sumber : Hasil Pengolahan Data Primer 2019

Dari tabel 4 menunjukan bahwa koefisien determinasi $\mathrm{R}^{2}$ pada nilai Adjusted R Square sebesar 0,579 artinya bahwa kemampuan variabel bebas dalam menjelaskan besarnya pengaruh terhadap variabel terikat sebesar 57,9\% sedangkan sisanya $42,1 \%$ merupakan faktor lain yang tidak diteliti.

\section{Pembahasan}

1. Pengaruh materi pelatihan terhadap kemampuan kerja karyawan PD BPR Bantul Yogyakarta.

Hasil penelitian ini mendukung hipotesis pertama $\left(\mathrm{H}_{1}\right)$ yaitu materi pelatihan berpengaruh positif dan signifikan terhadap kemampuan kerja karyawan PD BPR Bantul Yogyakarta. Hal ini dibuktikan dengan koefisien regresi materi pelatihan $\left(\mathrm{X}_{1}\right)$ sebesar 0.407 bertanda positif dan nilai signifikan 0,008 yang lebih kecil dari $\alpha=0,05$. Artinya, jika karyawan diberikan materi pelatihan yang sesuai dengan tujuan pelatihan maka pengetahuan yang dimiliki karyawan dapat bertambah, karyawan akan lebih terampil, dan secara menyeluruh kemampuan karyawan akan meningkat. Hasil penelitian ini juga didukung oleh teori Kasmir (2016) yang menyatakan bahwa materi pelatihan merupakan bahan ajar yang akan diberikan kepada peserta pelatihan. Kedalaman materi yang diberikan akan menambah pengetahuan peserta menjadi lebih baik. Kedalaman 
materi dapat membantu karyawan dalam mengasah kemampuan kerjanya. Oleh karena itu, pemilihan materi pelatihan juga harus disesuaikan dengan tujuan yang dicapai. Materi pelatihan harus diberikan secara sistematis dan berdasarkan tahapantahapan sehingga dapat berpengaruh terhadap kemampuan kerja

Hasil penelitian ini diperkuat secara empiris dari penelitian terdahulu oleh Rizaldi Aga Pratama dan Mochamad Djudi Mukzam (2018), yang hasilnya adalah secara parsial variabel metode pelatihan dan materi pelatihan berpengaruh signifikan terhadap variabel kemampuan kerja karyawan PT Perkebunan Nusantara X Pabrik Gula Pesantren Baru Kediri

\section{Pengaruh on the job training terhadap kemampuan kerja karyawan PD BPR Bantul Yogyakarta.}

Hasil penelitian ini mendukung hipotesis kedua $\left(\mathrm{H}_{2}\right)$ yaitu on the job training berpengaruh positif dan signifikan terhadap kemampuan kerja karyawan PD BPR Bantul Yogyakarta. Hal ini dibuktikan dengan koefisien regresi variabel on the job training $\left(\mathrm{X}_{2}\right)$ sebesar 0,312 bertanda positif dan nilai signifikan sebesar 0,036 yang lebih kecil dari $\alpha=0,05$. Hal ini menunjukkan bahwa jika metode pelatihan on the job dilaksanakan dengan baik dan tepat maka akan mampu meningkatkan kemampuan kerja karyawan PD BPR Bantul Yogyakarta.

Hasil penelitian ini sesuai dengan teori yang disusun oleh Bangun (2012), yang menyatakan bahwa metode on the job training merupakan metode yang paling banyak digunakan perusahaan, karena karyawan dilatih sambil mengerjakan tugasnya dibawah bimbingan senior/atasan langsung, sehingga tidak perlu meninggalkan tugas dan mendapatkan timbal balik yang cepat atas prestasi yang dicapai karyawannya. Selain itu, metode on the job training, memberikan manfaat antara lain: 1) karyawan melakukan pekerjaan yang sesungguhnya bukan disimulasikan; 2) karyawan menerima instruksi dari seniornya yang lebih berpengalaman; 3) pelatihan informal, relatif tidak mahal, dan mudah dijadwalkan; 4) membina hubungan kerja sama antara karyawan dan pelatih; 5) sangat relevan dengan pekerjaan, biaya tunai yang relatif rendah, dan membantu memotivasi kinerja yang kuat (Simamora, 2006)

Hasil penelitian ini konsisten dan mendukung penelitian Dimas Anugrah, dkk, (2018) yang memperoleh hasil bahwa On The Job Training berpengaruh signifikan terhadap kemampuan kerja karyawan. Selanjutnya, penelitian ini menjelaskan bahwa teknik-teknik on the job training yang meliputi Coaching, Rotasi Jabatan, Simulasi, dan Presentasi Informasi secara simultan memiliki pengaruh yang signifikan terhadap Kemampuan Kerja Karyawan maupun Kinerja Karyawan.

\section{Pengaruh off the job training terhadap kemampuan kerja karyawan PD BPR Bantul Yogyakarta. \\ Hasil penelitian ini mendukung} hipotesis ketiga $\left(\mathrm{H}_{3}\right)$ yaitu off the job training berpengaruh positif dan signifikan terhadap kemampuan kerja karyawan PD BPR Bantul Yogyakarta. Hal ini dibuktikan dengan koefisien regresi variabel off the job training $\left(\mathrm{X}_{3}\right)$ sebesar 0.443 bertanda positif dan nilai signifikan sebesar 0,000 yang lebih kecil dari $\alpha=0,05$

Temuan ini di dukung dengan teori yang sampaikan oleh Simamora (2006), bahwa hal yang paling menarik bagi karyawan pada off the job training, adalah pelatihan off the job diselenggarakan dilokasi dan waktu yang terpisah dari waktu kerja reguler, sehingga karyawan mempunyai 
kesempatan untuk bertukar pengalaman dengan karyawan lainnya dari luar lingkungan unit kerjanya, mendapatkan ide-ide baru yang dapat dibawa kembali ke tempat kerjanya, serta memperoleh wawasan yang lebih luas. Selain itu, off the job training memberikan manfaat antara lain : 1) biaya pelatihan efisien, karena dilakuakan secara berkelompok dan bukan individu yang dilatih. 2) pelatih biasanya lebih kompeten daripada on the job trainer yang biasanya hanya mengorbankan sebagian kecil waktunya untuk melatih; 3) kursus / seminar yang off site memampukan perusahaan kecil dengan sumber daya yang terbatas untuk melatih karyawan tanpa mengeluarkan biaya yang mahal untuk staf pelatih dan fasilitas pelatihan; 4) membuka wawasan karyawan terhadap perusahaan lain dengan mempelajari metode dan teknik baru disamping materi yang disajikan selama pelatihan; 5) memampukan karyawan berkonsentrasi untuk mempelajari keahlian dan sikap baru tanpa harus sekaligus mengkhawatirkan pelaksanaan pekerjaan; 6) mengurangi resiko bagi organisasi untuk mengkaryakan karyawan yang tidak memiliki pengetahuan yang memadai.(Simamora, 2006)

Secara empiris, hasil penelitian ini mendukung hasil penelitian Eriza Violanda Ekarendyka,dkk.(2016) pada Karyawan AUTO 2000 Malang-Sutoyo bagian divisi servise yaitu terdapat pengaruh yang signifikan on the job training dan off the job training terhadap kemampuan kerja. Kemampuan kerja berstatus sebagai variabel moderator atau penguat dalam hubungan off the job training terhadap kinerja karyawan. Hal ini berarti off the job training akan mampu menaikkan kinerja lebih besar jika melalui peningkatan kemampuan kerja.
4. Pengaruh variabel materi pelatihan, on the job training, dan off the job training secara simultan terhadap kemampuan kerja karyawan PD BPR Bantul Yogyakarta.

Hasil penelitian ini mendukung hipotesis keempat $\left(\mathrm{H}_{4}\right)$. yaitu materi pelatihan, on the job training, dan off the job training secara simultan berpengaruh signifikan terhadap kemampuan kerja karyawan PD BPR Bantul Yogyakarta. Hal ini dibuktikan dengan nilai signifikansi uji $\mathrm{F}$ sebesar 0,000 yang sangat jauh dari toleransi kesalahan sebesar $\alpha=0,05$ atau 5\%. Hal ini menunjukkan bahwa jika pemilihan materi pelatihan tepat dan metode pelatihan on the job maupun off the job disesuaikan dengan kondisi yang dihadapi peserta pelatihan maka pelaksanaan pelatihan kerja mampu meningkatkan kemampuan kerja karyawan PD BPR Bantul Yogyakarta.

Selain itu, hasil perhitungan koefisien determinasi diperoleh nilai Adjusted $\mathrm{R}^{2}$ sebesar 0,579. Artinya, sumbangan pengaruh variabel materi pelatihan $\left(\mathrm{X}_{1}\right)$, on the job training $\left(\mathrm{X}_{2}\right)$ dan off the job training $\left(\mathrm{X}_{3}\right)$ terhadap variabel kemampuan kerja (Y) sebesar $57,9 \%$, sedangkan sisanya sebesar $42,1 \%$ dipengaruhi oleh faktor lain diluar penelitian ini. Lebih lanjut, $\mathrm{R}^{2}$ dan uji $F$ bersifat sejalan/saling menggantikan (Gujarati 1995), artinya keberartian $\mathrm{R}^{2}$ diterima jika nilai $\mathrm{F}$ hitung > 4. Hasil $\mathrm{F}$ hitung sebesar 28,483 (lebih besar dari 4) berarti model penelitian sudah tepat (fit), dalam arti pemilihan variabel penelitian sudah tepat. Dengan demikian, variasi variabel bebas (materi pelatihan, on the job training, dan off the job training) dalam menjelaskan variabel terikat (kemampuan kerja), bisa diterima. 


\section{Simpulan}

Berdasarkan analisis data dan pembahasan hasil penelitian diperoleh kesimpulan sebagai berikut :

1. Materi pelatihan $\left(\mathrm{X}_{1}\right)$ berpengaruh positif dan signifikan terhadap kemampuan kerja(Y) karyawan PD BPR Bantul Yogyakarta. Hal ini dibuktikan dari koefisien regresi variabel kemampuan kerja $\left(\mathrm{X}_{1}\right)$ sebesar 0.407 bertanda positif dan nilai signifikan sebesar 0,008 yang lebih kecil dari $\alpha=0,05$. Dengan demikian, hipotesis pertama $\left(\mathrm{H}_{1}\right)$ dapat diterima.

2. On the job training $\left(\mathrm{X}_{2}\right)$ berpengaruh positif dan signifikan terhadap kemampuan kerja (Y) karyawan PD BPR Bantul Yogyakarta. Hal ini dibuktikan dari koefisien regresi variabel on the job training $\left(\mathrm{X}_{2}\right)$ sebesar 0,312 bertanda positif dan nilai signifikan sebesar 0,036 yang lebih kecil dari $\alpha=0,05$. Dengan demikian, hipotesis kedua $\left(\mathrm{H}_{2}\right)$ dapat diterima.

3. Off the job training $\left(\mathrm{X}_{3}\right)$ berpengaruh positif dan signifikan terhadap kemampuan kerja (Y) karyawan PD BPR Bantul Yogyakarta. Hal ini dibuktikan dari koefisien regresi variabel off the job training $\left(\mathrm{X}_{3}\right)$ sebesar 0.443 bertanda positif dan nilai signifikan sebesar 0,000 yang lebih kecil dari $\alpha=0,05$. Dengan demikian, hipotesis ketiga $\left(\mathrm{H}_{3}\right)$ dapat diterima

4. Materi pelatihan $\left(\mathrm{X}_{1}\right)$, on the job training $\left(\mathrm{X}_{2}\right)$, dan off the job training $\left(\mathrm{X}_{3}\right)$ secara simultan berpengaruh signifikan terhadap (Y) karyawan PD BPR Bantul Yogyakarta. Hal ini dibuktikan dari koefisien $\mathrm{F}$ hitung sebesar 28,483; nilai signifikan sebesar 0,000 yang lebih kecil dari 0,05, dan hasil adjusted $\mathrm{R}^{2}$ sebesar 0,579 . Dengan demikian, hipotesis keempat $\left(\mathrm{H}_{4}\right)$ dapat diterima.

\section{Implikasi}

Penelitian ini memunculkan implikasi praktis bagi karyawan dan PD BPR Bantul Yogyakarta bahwa pelatihan kerja khususnya tentang materi pelatihan, on the job training,dan off the job training mempengaruhi kemampuan kerja karyawan. Artinya ketika karyawan memperoleh pelatihan dengan baik maka kemampuan kerja karyawan akan semakin baik pula.

Sedangkan, PD BPR Bantul perlu mempertahankan dan terus meningkatkan pemberian pelatihan kerja secara berkesinambungan kepada karyawan, yang dapat dilakukan sejak awal penempatan karyawan bekerja agar karyawan dapat beradaptasi dalam menghadapi dan mengatasi berbagai permasalahan kerja. Dengan demikian karyawan mendapat dukungan instansi untuk mengembangkan diri dan meningkatkan kemampuan kerjanya demi kemajuan perusahaan.

\section{Saran}

Berdasarkan hasil pembahasan dan kesimpulan di atas, saran yang diberikan yaitu :

1. Bagi pihak manajerial PD BPR Bantul.

a. Mengacu pada hasil penelitian yang menunjukkan bahwa semua variabel bebas (materi pelatihan, on the job training, off the job training) mempunyai pengaruh yang signifikan terhadap kemampuan kerja karyawan, maka hendaknya instansi lebih sering melaksanakan pelatihan bagi para karyawannya agar para pegawai dapat mengembangkan 
kemampuan mereka dalam bekerja sehingga mereka dapat menghasilkan standar kerja yang diharapkan instansi

b. Pemberian pelatihan perlu dikembangkan dalam beberapa hal, misalnya tentang materi pelatihan. Materi yang diberikan harus mudah dimengerti oleh para peserta/karyawan dan disesuaikan dengan pekerjaannya; untuk metode pelatihan, perlu ditingkatkan pengarahan untuk trainer dari karyawan senior yang berpengalaman dan perlu ditingkatkan pelatihan untuk di luar tempat kerja dengan harapan karyawan akan menambah pengalamannya dan ilmu pengetahuannya; untuk fasilitas pelatihan, perlu ditingkatkan alat peraga pelatihan.

2. Bagi Akademisi.

Hasil penelitian ini menunjukkan bahwa koefisien determinasi Adjusted $\mathrm{R}^{2}$ sebesar 0,579. Artinya, sumbangan pengaruh variabel materi pelatihan $\left(\mathrm{X}_{1}\right)$, on the job training $\left(\mathrm{X}_{2}\right)$ dan off the job training $\left(\mathrm{X}_{3}\right)$ terhadap variabel kemampuan kerja (Y) sebesar 57,9 \% , sedangkan sisanya sebesar $42,1 \%$ dipengaruhi oleh faktor lain diluar penelitian ini. Oleh karena itu, para peneliti lain dapat mengadakan penelitian lanjutan dengan obyek yang sama tetapi variabel-variabel penelitian berbeda dari variabel yang digunakan dalam penelitian ini. Dengan demikian, PD BPR Bantul memiliki referensi yang cukup memadai dalam rangka meningkatkan kemampuan kerja karyawannya melalui pemberian pelatihan kerja.

\section{DAFTAR PUSTAKA}

Ardian, Dimas Anugrah dkk. 2018. "Pengaruh On The Job Training dan Off The Job Training Terhadap Kemampuan Kerja dan Kinerja (Studi pada karyawan PT. Insastama Kediri, Jawa Timur)"Jurnal Administrasi Bisnis (JAB) Vol. 62 No. 1 September 2018.(online)

http://administrasibisnis.studentjournal. ub.ac.id/index.php/jab/article/viewFile/ 2664/3058 (diunduh 2 september 2019)

Bangun, Wilson. 2012. Manajemen Sumber Daya Manusia, Jakarta: Erlangga

Edi Sutrisno. 2016. Manajemen Sumber Daya Manusia. Jakarta : Prenadamedia Group

Ekarendyka, Eriza Violanda dkk.2016. "Pengaruh Pelatihan Terhadap Kemampuan Kerja dan Kinerja Karyawan” (Studi pada Karyawan AUTO 2000 Malang-Sutoyo bagian divisi servise).(online). https://media.neliti.com/media/public ations/73822-ID-pengaruh-pelatihanterhadap-kemampuan-ke.pdf (diunduh 3 september 2019)

Gomes, Faustino Cardoso. 2003. Manajemen Sumber Daya Manusia. Yogyakarta: C.V ANDI OFFSET.

Gujarati, Damodar, 1995. Ekonometrika Dasar. Penerbit Erlangga, Jakarta

Blanchard, H, Paul, Hersey and Kenneth. 2005. Management of Organizational Behavior:Utilizing Human Resources.4thEd. [terjemahan]. Jakarta: Erlangga 
Hamalik, Oemar.2005. Perencanaan Pengajaran Berdasarkan Pendekatan Sistem. Jakarta: PT.Bumi Aksara.

Hersey, Paul dan Kenneth. H. Blanchard, 2000. Manajemen Perilaku Organisasi: Pendayagunaan Sumber Daya Manusia, Terjemahan Agus Dharma, Erlangga, Jakarta.

Hasibuan, Malayu SP. 2009. Manajemen Sumber Daya Manusia. Jakarta: Bumi Aksara

Handoko, Hani. 2014. Manajemen Personalia dan Sumber Daya Manusia. Yogyakarta: BPFE.

Hasibuan, H. Malayu. 2011. Manajemen Sumber Daya Manusia, edisi revisi. Jakarta: PT Bumi Aksara

Hermawan, Asep. 2009. Penelitian Bisnis. Jakarta: Grasindo.

Jogiyanto.2016.Pedoman Survai Kuisioner (Mengembangkan Kuisioner, Mengatasi Bias, Dan Meningkatkan Respon). Yogyakarta: BPFE-Yogyakarta Anggota IKAPI No.008.

Kasmir. 2016. Manajemen Sumber Daya Manusia (teori dan praktik), Edisi 1. Jakarta: Rajagrafindo Persada

Kurniawati. 2015. Pengembangan Sumber Daya Manusia. Jakarta: UT. Mathis, R.L. \& Jackson, J.H. (2006). Human Resources Management (10th ed.). Jakarta: Salemba Empat

Mangkunegara, A.P. 2013. Manajemen Sumber Daya Manusia (7th ed.). Bandung: $\quad$ PT Remaja Rosdakarya Miftah Thoha. 2012. Perilaku Organisasi Konsep Dasar dan
Implikasinya. Jakarta: $\quad$ PT Raja Grafindo Persada

Nitisemito, A.S. 2002. Manajemen Personalia. Ghalia Indonesia

Pratama, Rizaldi Aga dan Mochamad Djudi Mukzam .2018. "Pengaruh Metode Pelatihan dan Materi Pelatihan Terhadap Kemampuan Kerja dan Kinerja Karyawan" (Studi Pada Karyawan Tetap PT Perkebunan NusantaraX Pabrik Gula Pesantren Baru Kediri). Jurnal Administrasi Bisnis (JAB)|Vol. 62 No. 2 September 2018. (online). http://administrasibisnis.studentjournal. ub.ac.id/index.php/jab/article/viewFile/ 2668/3062 (diunduh 2 september 2019)

Rivai, Veithzal dan Ella Jauvani Sagala.2014.Manajemen Sumber Da ya Manusia untuk Perusahaan. Jakart a: PT Rajagrafindo Persada, .

Robbins, Stephen dan Judge. 2015. Perilaku Organisasi. Jakarta: Salemba Empat

Sagala, Syaiful .2011. Konsep dan Makna Pembelajaran. Bandung: Alphabeta

Simamora, Henry. 2006. Manajemen Sumber Daya Manusia, edisi ketiga. Yogyakarta: STIE YKPN,

Slameto. 2010. Belajar dan FaktorFaktor Yang Mempengruhinya. Jakarta: Rineka Cipta.

Silalahi, Ulber. 2010. Metode Penelitian Sosial. Bandung: PT. Refika Aditama.

Sugiyono. 2014. Metode Penelitian Kualitatif Dan Kuantitatif $R \& D$. Cetakan 20. Bandung: CV.Alfabeta 
Sudarmanto. 2009. Kinerja dan Pengembangan Kompetensi SDM (Teori, Dimensi Pengukuran dan Implementasi dalam Organisasi).Yogyakarta: Pustaka Pelajar

Swasto, Bambang. 2003. Pengembangan Sumber Daya Manusia (Pengaruhnya Terhadap Kinerja Karyawan dan Imbalan). Malang: Bayumedia

Swasto, Bambang. 2011. Manajemen Sumber Daya Manusia. Malang: Universitas Brawijaya Press (UB Press).

Wibowo. 2015. Perilaku Dalam Organisasi, Edisi 2,Cetakan 3. Jakarta: Rajawali Pers

Wursanto, I.G. 2003. Dasar-Dasar Perilaku Organisasi.Yogyakarta : Andi 